\title{
NT-proBNP LEVEL CHANGES AFTER COMBINATION THERAPY WITH BISOPROLOL AND ACE-INHIBITOR IN PATIENT WITH HEART FAILURE
}

\author{
Reine Risa Risthanti ${ }^{1}$, Muhammad Aminuddin ${ }^{2}$, Suharjono ${ }^{3}$ \\ ${ }^{1}$ Master of Clinical Pharmacy Program, Faculty of Pharmacy, Universitas Airlangga, ${ }^{2}$ Department of Cardiology, \\ Dr. Soetomo Teaching Hospital, Surabaya, 3Clinical Pharmacy Department, Faculty of Pharmacy, Universitas \\ Airlangga
}

\begin{abstract}
ABSTRAK
Gagal jantung merupakan tahap akhir dari berbagai kondisi yang menyebabkan penurunan kapasitas jantung. Peningkatan kadar NT-proBNP berhubungan dengan stress dinding ventrikel dan keparahan gagal jantung. Pemberian Bisoprolol dan ACE inhibitor pada pasien gagal jantung dapat menurunkan kadar NT-proBNP. Di Poli Jantung RSUD Dr. Soetomo, penggunaan Bisoprolol sebagai terapi kombinasi dengan ACE-inhibitor cukup banyak. Tujuan penelitian ini adalah untuk menganalisa perubahan kadar NT-proBNP sebagai indikator fungsi jantung pasca 2 bulan terapi Bisoprolol dan ACE-inhibitor. Jenis penelitian adalah observasional pre-analitik secara prospektif dengan desain penelitian one group pretest-posttest. Penelitian dilakukan pada pasien gagal jantung yang memenuhi kriteria inklusi selama Agustus-November 2015. Sampel darah diambil pada saat pre dan 2 bulan pasca terapi kombinasi Bisoprolol dan ACE-inhibitor, kemudian kadar NT-proBNP ditentukan dengan alat IMMULITE®. Terdapat empat belas pasien yang memenuhi kriteria inklusi (laki-laki:perempuan =1:1). Pasca 2 bulan terapi kombinasi Bisoprolol dan ACE-inhibitor, terjadi penurunan rerata kadar NT-proBNP yang signifikan antara pre dan post yaitu dari 4191,43 $\pm 4367,277 \mathrm{pg} / \mathrm{ml}$ menjadi 2786,79 $\pm 2485,199 \mathrm{pg} / \mathrm{ml}$ ( $p=0,025)$. Dari total 14 pasien, sebanyak 9 pasien menunjukkan penurunan kadar NT-proBNP $>20 \%$ (20,1\% - 56,4\%). Selanjutnya, sebanyak 3 pasien menunjukkan penurunan kadar NT-proBNP <20\% (6,6\%; 1,8\%; dan 12,38\%). Sedangkan 2 pasien menunjukkan peningkatan kadar NT-proBNP >40\% (43,4\% dan 40,4\%). Terjadi penurunan yang signifikan pada kadar NT-proBNP pasca terapi kombinasi Bisoprolol dan ACE-inhibitor. Dengan mempertimbangkan manfaat NTproBNP untuk menilai keberhasilan terapi gagal jantung, maka dapat dilakukan penelitian lebih lanjut dengan waktu yang lebih lama dan jumlah sampel yang lebih besar serta variabel perancu yang lebih terkendali. (FMI 2016;52:258-263)
\end{abstract}

Kata kunci: NT-proBNP, gagal jantung, Bisoprolol, Angiotensin-converting enzyme inhibitors

\begin{abstract}
Heart failure $(H F)$ is the final common stage of many diseases of the heart. NT-proBNP levels are increased in HF and correlate well with ventricular wall stress and severity of HF. Combination therapy with Bisoprolol and ACE-inhibitor decreases NT-proBNP level in patient with HF. The use of Bisoprolol as a combination with ACE-inhibitor is still dominate in outpatient setting at Dr. Soetomo teaching hospital. The objective of this study is to analyze NT-proBNP level changes as an indicator in cardiac function after combination therapy with Bisoprolol and ACE-inhibitor in patient with HF.Methods: This study was prospective, observational and conducted in outpatient setting. Consecutive patients who meet the inclusion criteria of the study were included. Blood samples were taken at pre and 2 months post combination therapy with Bisoprolol and ACE-inhibitor, then NT-proBNP level was measured with IMMULITE®. There were 14 patients enrolled in this study (7 males, 7 females). The result showed that NT-proBNP 2 months post combination therapy with Bisoprolol and ACE-inhibitor is significantly decreased than baseline with mean baseline of NTproBNP level is $4191.43 \pm 4367.277 \mathrm{pg} / \mathrm{ml}$ to $2786.79 \pm 2485.199 \mathrm{pg} / \mathrm{ml}(\mathrm{p}=0.025)$. From a total 14 patients, 9 patients had NTproBNP decreases $>20 \%(20.1 \%-56.4 \%)$ and 3 patients had NT-proBNP decreases $<20 \%(1.8 \%$, $6.6 \%$, and $12.4 \%)$. There were 2 patients with NT-proBNP increases $>40 \%$ (43.4\% and 40.4\%). In conclusion, there was a significant decreases in NT-proBNP level after 2 months combination therapy with Bisoprolol and ACE-inhibitor in patient with HF. (FMI 2016;52:258-263)
\end{abstract}

Keywords: NT-proBNP, heart failure, Bisoprolol, Angiotensin-converting enzyme inhibitors

Correspondence: Reine Risa Risthanti, Gunung Anyar Tengah 2B/12 Surabaya. Phone: +6281335668194.

e-mail: risthanti@gmail.com

\section{INTRODUCTION}

Heart failure is a clinical syndrome that occurs in patients who, because of an inherited or acquired abnormality of cardiac structure and or function, develop a constellation of clinical symptoms (dyspnea and fatigue) and signs (edema and rales) that lead to frequent hospitalizations, a poor quality of life, and a shortened life expectancy (Brunton 2011, Longo et al 2012). Along with decreased capacity of the heart, the various compensatory mechanisms are activated, such as adrenergic nervous system, the renin-angiotensin 
system, and cytokines. The neuro-hormonal activation effect vasoconstriction and fluid retention which can lead to increased ventricular wall stress. Overexpression of these various systems can lead to secondary end organ damage to the ventricles. Then, a number of counterregulatory system of neurohormonal would be activated to offset these negative effects. The natriuretic peptides, including atrial natriuretic peptide (ANP) and brain-type natriuretic peptide (BNP), are one of the most important counterregulatory neurohormonal systems that become activated in HF (Bonow et al 2012).

B-type natriuretic peptide (BNP) can be measured in serum and plasma as a biologically active portion BNP and as an amino terminal portion NT-proBNP. Ventricular wall stretch is the major determinant of increased BNP concentrations in heart failure patients. BNP has a very high negative predictive value for the identification of persons with left ventricular systolic dysfunction and heart failure. Higher concentrations of BNP are associated with increased cardiovascular and all cause mortality, independently of age, New York Heart Association (NYHA) class, and ejection fraction. The prognostic power of BNP is well established in heart failure patients; serial determination of BNP can improve prognostic information in compensated and decompensated heart failure patients (Bettencourt 2005). Effective therapy in patients with heart failure, such as the administration of ACE inhibitors and ?blockers, can reduce levels of NT - proBNP plasma (Olsson et al 2007).

The aim of this study was to analyze NT-proBNP level changes as a biomarker in heart failure after combination therapy with Bisoprolol and ACE-inhibitor in outpatient setting at Cardiology Department Dr. Soetomo Teaching Hospital.

\section{MATERIALS AND METHODS}

A prospective observational study was conducted in outpatient setting at Cardiology Department Dr. Soetomo Teaching Hospital during August-November 2015. Patient selection based on inclusion and exclusion criteria. Inclusion criteria (1) patient diagnose with heart failure NYHA II and III aged 21-75 years old; (2) Have never been or have received combination therapy and ACE - inhibitors Bisoprolol maximum of 3 months earlier; (3) patient or family agreed follow study. Patient with potassium serum $>5 \mathrm{mg} / \mathrm{dL}$, eGFR $<50 \mathrm{ml} / \mathrm{min} /$ $1.73 \mathrm{~m}^{2}$, and BMI $>30 \mathrm{~kg} / \mathrm{m}^{2}$ were excluded. Ethical clearance of this study was held at Dr. Soetomo Teaching Hospital.
Blood samples were collected from all patient at pre and 2 months post combination therapy with Bisoprolol and ACE-inhibitor to analyze NT-proBNP level. The blood collected for NT-proBNP measurement was centrifuged and kept at $50 \mathrm{C}$ until the time of of the measurement. NT-proBNP measurement was performed by IMMULITE® device. Descriptive analyses were performed to determine characteristics of patients and profile of therapy. The diference between NT-proBNP level pre and post was measured by paired t-test. A probability value of 0.05 regarded as significant.

\section{RESULTS}

During the study period showed 17 patients who met the inclusion criteria, but 3 patients had to drop out because the patient does not return when the data retrieval posttest and sample through lysis, so that the number of patients being used as a sample in this study were 14 patients. Baseline characteristic of patients are shown in Table 1. The mean age of patients is 50.3 years (range 32-73 years) and included 7 females and 7 males. The type of patient diagnosis consists of coronary heart disease and old myocard infarct $(35.7 \%)$, hypertension heart failure $(28.6 \%)$, and valvular heart disease $(35.7 \%)$. Atrial fibrilation was present in 4 patients.

Table 1. Characteristics of Patients HF

\begin{tabular}{llc}
\hline \multicolumn{2}{c}{ Characteristic $(\mathrm{n}=14)$} & $\mathrm{n}(\%)$ \\
\hline Sex & Female & $7(50 \%)$ \\
Age & Male & $7(50 \%)$ \\
Diagnose & 52 years & $7(50 \%)$ \\
& $>52$ years & $7(50 \%)$ \\
& OMI & $5(35.7 \%)$ \\
Complication & HHF & $4(28.6 \%)$ \\
& VHD & $5(35.7 \%)$ \\
NYHA & AF & $4(28.6 \%)$ \\
& II & $12(85.7 \%)$ \\
Medication & III & $2(14.3 \%)$ \\
& Bisoprolol & $14(100 \%)$ \\
& Ramipril & $10(72 \%)$ \\
& Lisinopril & $3(21 \%)$ \\
& Captopril & $1(7 \%)$ \\
& Furosemide & $11(78.6 \%)$ \\
& Spironolactone & $12(85.7 \%)$ \\
\hline
\end{tabular}

Percentage changes in NT-proBNP levels pre and post combination therapy Bisoprolol and ACE-inhibitor are shown in Table 2. The mean percentage changes of NTproBNP level is $22.5 \%$. From a total 14 patients, 9 patients had NT-proBNP decreases >20\% (20.1\%$56.4 \%$ ) and 3 patients had NT-proBNP decreases $<20 \%$ 
$(1.8 \%, 6.6 \%$, and $12.4 \%)$. There were 2 patients with NT-proBNP increases $>40 \%$ (43.4\% and $40.4 \%)$.

Table 2. Precentage Changes of NT-proBNP Level

\begin{tabular}{cccccc}
\hline \multirow{2}{*}{ Sample } & \multicolumn{2}{c}{ NT-proBNP $(\mathrm{pg} / \mathrm{ml})$} & & $\begin{array}{c}\Delta \mathrm{NT}- \\
\text { proBNP } \\
(\mathrm{pg} / \mathrm{ml})\end{array}$ & $\begin{array}{c}\% \Delta \mathrm{NT}- \\
\text { proBNP }\end{array}$ \\
\cline { 2 - 3 } & Pre & Post & & 239 & 20.6 \\
2 & 1161 & 922 & & 759 & 20.5 \\
3 & 3701 & 2906 & & -105 & -43.4 \\
4 & 442 & 347 & & -416 & 20.1 \\
5 & 653 & 3640 & 610 & 43 & 6.6 \\
6 & 7306 & 5512 & 1794 & 24.6 \\
7 & 15031 & 7568 & 7463 & 49.7 \\
8 & 505 & 496 & 9 & 1.8 \\
9 & 1252 & 546 & 706 & 56.4 \\
10 & 9339 & 5959 & 3380 & 36.2 \\
11 & 292 & 410 & -118 & -40.4 \\
12 & 6683 & 5279 & 1404 & 21.0 \\
13 & 1445 & 1266 & 179 & 12.4 \\
14 & 6514 & 3554 & 2960 & 45.4 \\
\hline
\end{tabular}

There was a statistically significant diference between NT-proBNP pre and post with mean baseline of NTproBNP level is $4191.43 \pm 4367.277 \mathrm{pg} / \mathrm{ml}$ to $2786.79 \pm$ $2485.199 \mathrm{pg} / \mathrm{ml}(\mathrm{p}=0.025)$. The mean level of NTproBNP pre and post are shown in Table 3 and Figure 1.

Table 3. The mean level of NT-proBNP

\begin{tabular}{ccc}
\hline $\begin{array}{c}\text { Sample } \\
(\mathrm{n}=14)\end{array}$ & Range & P value \\
\cline { 2 - 2 } Pre & $242-15031$ & \\
& $(4191.43 \pm 4367.277)$ & $\begin{array}{c}\text { Paired } t \text {-test } \\
\mathrm{p}=0.025\end{array}$ \\
Post & $347-7568$ & \\
\hline
\end{tabular}

From a total 14 patients, there were 12 patients who showed decreased levels of NT-proBNP post combination therapy. A total of 4 patients (33.33\%) showed decreased levels of NT-proBNP $>25 \%$, while 8 patients $(66.67 \%)$ showed a decrease in NT - proBNP levels $<25 \%$. From a total 4 patients showed decreased levels of NT - proBNP $>25 \%, 3$ patients $(75 \%)$ received combination therapy Furosemide and Spironolactone, whereas 1 patient $(25 \%)$ received Spironolactone therapy alone.

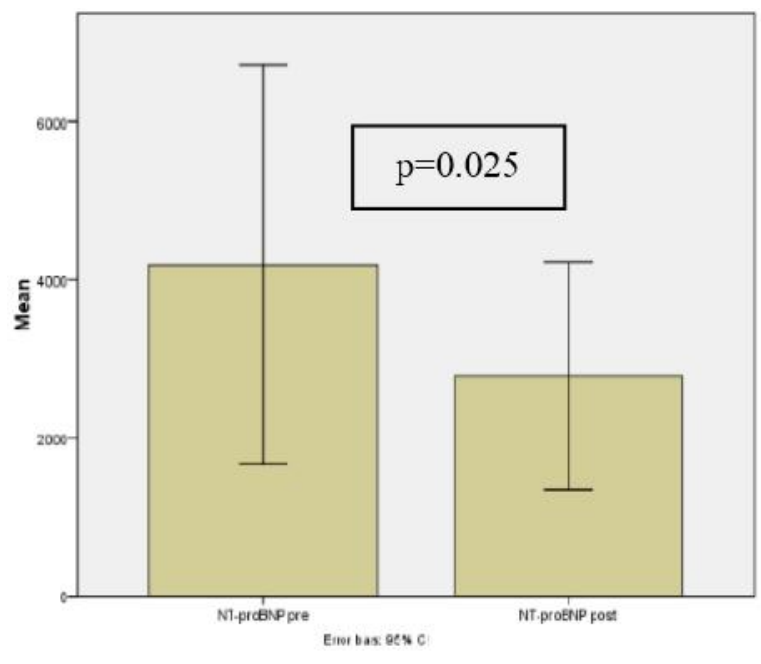

Fig. 1. Range of Nt-proBNP Level

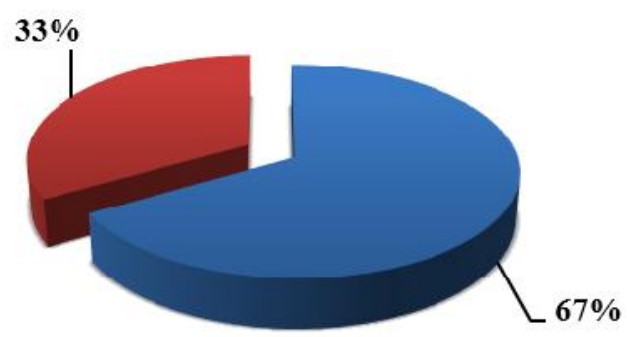

a decrease $<25 \% \quad$ decrease $>25 \%$

Fig. 2 Percentage number of patients shows decrease in NT-proBNP

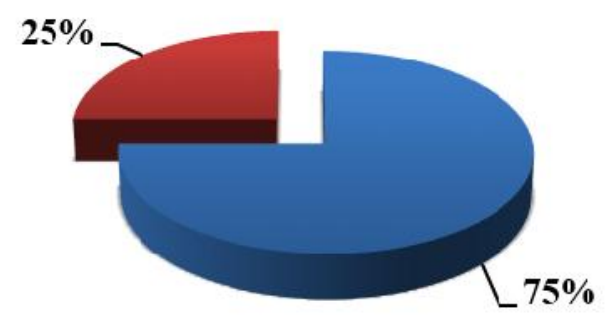

- Combination of Spironolactone and Furosemide

- Spironolactone alone

Fig. 3 Percentage number of patients shows decrease in NT-proBNP > $25 \%$ 


\section{DISCUSSION}

All patients in this study get a combination of Bisoprolol and ACE-inhibitors. The types of combination therapy Bisoprolol and ACE-inhibitors are used by patients divided into three kinds of combinations: a combination of Bisoprolol + Ramipril, Lisinopril + Bisoprolol, and Bisoprolol + Captopril. The combination of the most widely used is Bisoprolol + Ramipril (72\%) with a dose of $2.5 \mathrm{mg}$ Bisoprolol and $2.5 \mathrm{mg}$ Ramipril. In addition to combination therapy Bisoprolol and ACE-inhibitors, patients also received other therapies to treat the symptoms of heart failure. Furosemide and Spironolactone is another therapy that is most widely used by patients with their respective percentage of $85.7 \%$ for spironolactone and $78.6 \%$ for furosemide.

Provision of effective therapy in patients with heart failure, such as combination therapy Bisoprolol and ACE-inhibitors, can support a decrease in NT-proBNP plasma levels (Olsson et al 2007). Barriers sympathetic activity by $\beta$-blockers and barriers RAAS by ACE inhibitors, causing the decreases ventricular wall stress, lead to reduced levels of NT-proBNP (Jackson et al 2000 , Newby et al 2010). The efficacy of $\beta$-blockers for heart failure therapy has been evaluated in several randomized controlled clinical trial in heart failure patients with different etiologies and impaired systolic function. Results from these studies showed that $\beta$ blocker (Metoprolol succinate, Bisoprolol and Carvedilol) may improve ventricular ejection fraction and symptoms of heart failure, and reduce mortality and the incidence of hospital admission (Barrese \& Taglialatela 2013). The provision of long-term $\beta$ blockers can lower NT-proBNP levels and improve the function of the left ventricle, although the levels are slightly increased at the beginning of therapy. Titration dose of $\beta$-blockers after a comprehensive therapy, resulted in a further decline in the levels of BNP, in which it describes the process of reverse remodeling in the ventricle of the heart (Wang et al 2005, Porapakkham et al 2010). $\beta$-blockers could be given to patients who still show symptoms and EF are kept low, in addition to the provision of ACE-inhibitors and diuretics. The combination of $\beta$-blockers and ACEinhibitors complement each other and both should be given immediately after a patient is diagnosed HF-REF. ACE-inhibitors have an effect on $\mathrm{LV}$ remodeling whereas $\beta$-blockers provide significant improvement in EF (McMurray et al 2012).

ACE-inhibitor class that is most widely used by the patient in this study is Ramipril. As recommended ACC/AHA, Ramipril dosage given to patients with heart failure is $1.25-2.5 \mathrm{mg}$ given once daily. Doing so may improve patient adherence in outpatient setting therapy thus becomes more optimal therapeutic outcome. When compared with Captopril, the recommended dose is $6.25 \mathrm{mg}$ given three times a day, which can lead to non-adherence of patients due to forget in taking medicine. Such as Ramipril, Lisinopril is also frequently used by patients for consideration of patient compliance. The recommended dose is $2.5-5 \mathrm{mg}$ given once daily. NT-proBNP levels can be used as an estimation of prognosis in chronic heart failure. High levels of NT-proBNP and BNP are associated with increased mortality and incidence of hospital admission due to heart failure (Miller et al 2009). In this study, measurement of NT-proBNP levels pre and post combination therapy aims to analyze the changing levels of NT-proBNP for patients undergoing outpatient therapy. Based on these results, the mean percentage decrease was $22.5 \%$. A total of 9 patients showed a percentage decrease in the levels of NT-proBNP post combination therapy Bisoprolol and ACE-inhibitors in the range of $20.1 \%-56.4 \%$. According to Miller et al, NT-proBNP levels decrease by $20 \%-80 \%$ of baseline in outpatient setting can reduce the risk of death, transplantation, and the incidence of hospital admission. In addition based on the decrease of percentage against the baseline, NT-proBNP levels decrease to below the cutpoint $<1000 \mathrm{pg} / \mathrm{ml}$ (mean baseline of $5000 \mathrm{pg} / \mathrm{mg}$ ) can also decrease the risk of mortality, and the incidence of hospitalization (Miller et al 2009). A total of 3 patients experienced decreased levels of NT-proBNP post $<20 \%$, but a decrease in NT-proBNP levels are still below the cutpoint $(610 \mathrm{pg} / \mathrm{ml}$ and $496 \mathrm{pg} / \mathrm{ml})$, whereas 1 patient decreased levels of NT- proBNP post was slightly above the cutpoint (1266 pg/ml).

From all patients (14 patients), there were 4 patients with decreased levels of NT-proBNP to below the cutpoint. According to Amir et al, outpatients with high levels of NT-proBNP (> $2000 \mathrm{pg} / \mathrm{ml}$ ) had a risk 6 times higher the incidence of mortality and worsening of heart disease, including a decrease in ejection fraction, increased incidence of atrial fibrillation and renal function impairment as well as a shortening of the 6 minute walk test distance. Patients with elevated levels of NTproBNP in mild -range (> $500 \mathrm{pg} / \mathrm{ml}$ ) had a high risk, almost $10 \%$, the incidence of mortality during treatment (Amir et al 2008). Based on the results of paired t-test, showed that combination therapy with Bisoprolol and ACE-inhibitors significantly decrease the levels of NT-proBNP as a marker of cardiac stress $(\mathrm{p}=0.025)$. From 14 samples, the average show decreased levels of NT-proBNP post combination therapy, unless the sample number 3 and number 11 . In both samples, levels of NT-proBNP post have increased in the amount of $43.4 \%$ for the sample number 3 and $40.4 \%$ for the sample number 11 . In the sample number 
3, increased levels of NT-proBNP possibly due to interference with the patient's renal function. Patients eGFR value based on the calculation method MDRD was $54.22 \mathrm{ml} / \mathrm{min} / 1.73 \mathrm{~m} 2 \quad(<60 \quad \mathrm{ml} / \mathrm{min} / 1.73 \mathrm{~m} 2)$. Patients with impaired renal function are likely to have atrial pressure, systemic pressure, and ventricular mass were higher where it can trigger increased levels of natriuretic peptide physiological or rising levels can also be caused by a decrease in renal filtration, decreased clearance by NPR-C and endopeptidase, or a decrease in renal response to the BNP. BNP levels begin to increase in the threshold GFR of $60 \mathrm{ml} / \mathrm{min} / 1.73 \mathrm{~m} 2$. Increased natriuretic peptide in patients with impaired renal function describes the occurrence of LV hypertrophy. Clearance of NT-proBNP were not mediated by the receptor NPR-C or neutral endopeptidase, will be more sensitive than BNP to decrease renal filtration and clearance. Thus, the interpretation of NT-proBNP levels would be more difficult in patients with GFR $<60$ $\mathrm{ml} / \mathrm{min} / 1.73 \mathrm{~m} 2$ (Daniels and Maisel 2007). Sample number 11 is a new patient with a diagnosis of RHD + $\mathrm{MR}+$ DCFC II. On condition of mitral regurgitation, natriuretic peptide levels increased with increasing severity of mitral regurgitation (Daniels and Maisel 2007). In another study also mentioned that patients with RVD, NT-proBNP levels increased with severity of MS and severity of MR. The secretion of NP in patients with $\mathrm{MR}$ and/or MS is correlation with an increased LA wall stress compared to LV. The increase in NT-proBNP is a response to increased pressure or strain LA due to hemodynamic conditions in the MS. Severe MR may also increase the secretion of NTproBNP due to volume overload in LA (Davutoglu et al 2005).

The biological variation can influence the changes in the synthesis of NP, along with changes in cardiac filling pressure, pulmonary pressure, hemodynamics and change in the clearance of NT-proBNP. When the biological variation was higher, the biological variation of $25 \%$ of the NT-proBNP is expected. Thus, an increase or a decrease of $25 \%$ in NT-proBNP provides significant physiological changes (Januzzi 2012). There were 12 patients who showed decreased levels of NTproBNP post combination therapy. A total 4 patients $(33.33 \%)$ showed decreased levels of NT-proBNP > 25 $\%$, while 8 patients $(66.67 \%)$ showed a decrease in NTproBNP levels $<25 \%$. From a total 4 patients showed decreased levels of NT-proBNP > 25\%, 3 patients $(75 \%)$ received combination therapy Furosemide and Spironolactone, whereas 1 patient $(25 \%)$ received Spironolactone therapy alone. The use of drugs in heart failure therapy can modify the concentration of NP. Diuretics and vasodilators may decrease the concentration of NP quickly along with a decrease in intracardiac filling pressures. Spironolactone which is aldosteron antagonist can trigger a decrease in the concentration of NP (Bettencourt 2005, Troughton \& Richards 2008).

Our study has several limitations that may affect the study results. Limitations of this study include a short follow up time and a limited number of samples. The presence of confounding variables such as therapy used by patients (Spironolactone and Furosemide) can also affect the results of this study. Considering the benefits of NT-proBNP as an objective supporting data to assess the effectiveness of therapy in patients with heart failure, it can be suggested a further research with longer follow up time, a larger sample size and more controlled for confounding variables.

\section{CONCLUSION}

Our study showed a significant decreases in NTproBNP level after 2 months combination therapy with Bisoprolol and ACE-inhibitor in patient with heart failure.

\section{REFERENCES}

Amir, O., et al (2008). Usefulness and Predictive Value of Circulating NT-proBNP levels to Stratify Patients for Referral and Priority Treatment in a Specialized Outpatient Heart Failure Center. Nature Reviews Cardiology, 10:109-112

Barrese, V., and Taglialatela, M. (2013). New Advances in $\beta$-blocker Therapy in Heart Failure. Clinical and Translational Physiology, 4(323).

Bettencourt, P.M. (2005). Clinical Usefulness of B-type Natriuretic Peptide Measurement: Present and Future Perspectives. Heart, 91: p.1489-1494.

Bonow, R.O., Mann, D.L., Zipes, D.P., Libby, P. (2012). Braunwald's Heart Disease: A Textbook of Cardiovascular Medicine, 9th edition, Philadelphia: Elsevier Saunders.

Brunton, L.L. (2011). Goodman and Gilman's The Pharmacological Basis of Therapeutics, 12th Edition, New York: McGraw-Hill Companies, Inc.

Daniels, L.B., and Maisel, A.S. (2007). Natriuretic Peptides. Journal of The American College of Cardiology, 50:2357-68.

Davutoglu, V., et al. (2005). Plasma NT-Probnp Is A Potential Marker of Disease Severity and Correlates With Symptoms In Patients With Chronic Rheumatic Valve Disease. The European Journal of Heart Failure, 7:532- 536.

Jackson, G., Gibbs, C.R., Davies, M.K., and Lip, G.Y.H. (2000). ABC of Heart Failure: Pathophysiology, British Medical Journal, 320: 167-170. 
Januzzi, J.L. (2012). The Role Of Natriuretic Peptide Testing In Guiding Chronic Heart Failure Management: Review of Available Data and Recommendations For Use. Archives of Cardiovascular Disease, 105:40—50.

Longo. D.L., Kasper, D.L., Fauci, A.S., Hauser, S.L., and Loscalzo, J. (2012). Harrison's Principles of Internal Medicine, 18th Edition, New York: McGrawHill Companies, Inc.

McMurray, et al. (2012). ESC Guidelines for the diagnosis and treatment of acute and chronic heart failure. European Heart Journal. 33:1787-1847

Miller, W.L., et al. (2009). Only Large Reductions in Concentrations of Natriuretic Peptides (BNP and NTproBNP) Are Associated with Improved Outcome in Ambulatory Patients with Chronic Heart Failure. Clinical Chemistry 55:1; 74-84.
Newby, D.E., Grubb, N.R., Bradbury, A. (2010). Cardiovascular Disease. In: Colledge, N.R., Walker, B.R., and Ralston, S.H., Davidson's Principles and Practice of Medicine, 21th Edition, Elsevier Limited.

Olsson, L.G., et al. (2007). Prognostic Importance of Plasma NT-proBNP in Chronic Heart Failure in Patients Treated with $\beta$-blocker: Result from the Carvedilol or Metoprolol European Trial (COMET). European Journal of Heart Failure, 9: p.795-801.

Porapakkham, P., et al. (2010). A Meta-analysis: B-type Natriuretic Peptide-Guide Heart Failure Therapy. Archives of Internal Medicine, 170(6): p.507-514.

Wang, F., et al. (2005). Abstract: Beneficial Neurohormonal Profiles of $\beta$-blockades in Chronic Left Heart Failure. [Access April, 10 2015]. Available at: http://www.ncbi.nlm.nih.gov/pubmed/16080835 